\title{
Quantitative Analysis of and Discussion on Social Security Price of Farmland in Land Requisition Price"
}

\author{
Yapeng Zhou ${ }^{1}$, Lin $\mathrm{Liu}^{2,3}$, Yang Yang ${ }^{1}$, Ying Chen ${ }^{1}$, Hao Xu ${ }^{1}$, Wenting Zhao ${ }^{1, * *}$, \\ and $\mathrm{Na} \mathrm{Hao}{ }^{1}$ \\ ${ }^{1}$ College of Natural Resources \& Environment Sciences, Agricultural University of Hebei, \\ Baoding 071001, China \\ ${ }^{2}$ School of Land Science and Technology, China University of Geosciences, Beijing 100083, \\ China \\ ${ }^{3}$ Shijiazhuang Engineering Technology School, Shijiazhuang 050061, China \\ zhouyp@hebau.edu.cn, zwt1964b@sina.com
}

\begin{abstract}
This paper points out that the irrational calculation of the social security price of farmland leads to the relatively low price of the land requisition price. This paper begins with the analysis of the social security function of farmland to farmers and puts forward the idea that the social security value of farmland should include the following four aspects, namely, the value of the endowment insurance, the medical insurance, the job security and the inheritance of property. Based on the principle that the urban residents and the rural residents are equal and taking the pricing level of the social security system of residents into account, this paper quantifies the value of the four aspects of the social security value of farmland, adds up the four aspects, analyzes them and gets the social security price of farmland.
\end{abstract}

Keywords: Farmland, Social Security, Quantitative Analysis.

With the unceasing development of the market economy in China, radical changes have occurred to the employment system of enterprises and the traditional compensation and placement system cannot function well. Therefore, how to calculate the land requisition price of farmland in the new era rationally has become a major problem that needs resolving urgently. The social security price of farmland is an important part of its price structure, but the research into its calculation method is still limited to the theoretical research. Therefore, the research into the rational calculation method of social security price of farmland will provide a basis for building a sound land requisition pricing system of farmland $[1,2]$.

\section{Definition of Social Security Price of Farmland}

The social security system is the social service and measures provided by a state or a community so as to improve and enhance the material standards as well as the living standards of its residents, and it is also a sign of social civilization and social progress.

\footnotetext{
* The paper is supported by the Hebei Provincial Department of education funding for a project, (project number is 2009451)

** Corresponding author.
}

D. Li and Y. Chen (Eds.): CCTA 2012, Part I, IFIP AICT 392, pp. 444 450, 2013.

(C) IFIP International Federation for Information Processing 2013 
On March 22, 2005, the No. 233 file, Technical Guide to Setting Comprehensive Land Price in Requisition Area (Exposure Draft) issued by the General Office of Ministry of Land and Resources defined the social security price of farmland as "the due compensation accepted by farmers of whom land is requisitioned and does not get the basic living allowances, to receive education and reemployment training" [2,3]. Therefore, the social security price of farmland is monetized functions of the four aspects, namely, the endowment insurance, medical insurance, job security and inheritance of property for farmers.

\section{The Price Structure of Social Security Price of Farmland}

\subsection{The Function of Endowment Insurance}

Land provides not only a means of production for farmers in the contemporary age, but also a basis for their children to live by cultivating the land and support their elders.

\subsection{The Function of Medical Insurance}

Family has become the basic unit for farmers to get medical insurance. For most rural families, land is the most basic and most important means of production and land revenue is the most important or even the sole source of family security. Therefore, land is of important medical security function for farmers.

\subsection{The Function of Job Security}

Land is the important place for farmers to work on and live on and also basis for their subsistence. By means of working on land, farmers can obtain the basic security for their food and closing. They all amply show that land is of important job security function or basic subsistence guarantee function for farmers.

\subsection{The Function of Property Inheritance}

In accordance with relevant laws, land is of property inheritance function for farmers, it not only guarantees the basic subsistence of farmers, but also provides their offspring with the basic survival conditions $[3,4]$.

\section{The Calculation of Social Security Price of Farmland}

The new edition of The Law of Land Administration adopts the "method of multiplicity of production value" to calculate the placement and compensation fee (i.e. the social security price). This kind of calculation is very subjective and lacks a reasonable basis, and thus the result fails to reveal the social security value of land. Therefore, this paper will calculate the endowment insurance price of land, medical insurance price of land, 
job security price of land and property inheritance price of land respectively, then add them up, modify them reasonably and finally obtain the social security price of land [4].

At present, more and more farmers will leave their land, and thus the social security value of land will gradually be replaced by the social security system of the state, and farmers will enjoy the same social security as that of the urban residents. Therefore, when the social security price of land is calculated, the choice of the parameters as well as the value can consult the social security standards of the urban residents, i.e. reach uniformity between urban residents and rural residents.

\subsection{Calculation of Endowment Insurance Price}

The endowment insurance price of the requisitioned land should be calculated based on the amount of money paid for the individual endowment insurance. By reference to the endowment insurance system of urban residents and taking the individual endowment insurance, scale of premium rate of Taipingshengshi Changshou endowment insurance A (see Table 1) of China Pacific Insurance Co., Ltd. as an example, the per capita single premium of endowment insurance can be calculated based on the following equation.

$\mathrm{Ye}=(\mathrm{Yma} \times \mathrm{Bm}+\mathrm{Ywa} \times \mathrm{Bw}) \times \mathrm{Mi} / \mathrm{Mo}$

In this equation, $\mathrm{Ye}$ - the per capita single premium of endowment insurance

a-average age

Yma-base number of the single premium of endowment insurance of male citizens at the age of a

Ywa-base number of the single premium of endowment insurance of female citizens at the age of a

$\mathrm{Bm}$ - the proportion of male population to the total population

$\mathrm{Bw}$ - the proportion of female population to the total population

$\mathrm{Mi}$ - basic allowances of farmers (insurance benefit standard per month)

Mo-base number of the premium per month

Table 1. Scale of Premium Rate of Taipingshengshi Changshou Endowment Insurance A of China Pacific Insurance Co., Ltd.(Male citizens get insurance benefit when they reach 60 years old, while female citizens reach 55 and both get 100 yuan each month) unit : yuan

\begin{tabular}{cccccc}
\hline $\begin{array}{c}\text { Purchasing } \\
\text { Insurance at } \\
\text { the Age of }\end{array}$ & $\begin{array}{c}\text { Single } \\
\text { Premium for } \\
\text { Males }\end{array}$ & $\begin{array}{c}\text { Single } \\
\text { Premium for } \\
\text { Females }\end{array}$ & $\begin{array}{c}\text { Purchasing } \\
\text { Insurance at } \\
\text { the Age of }\end{array}$ & $\begin{array}{c}\text { Single } \\
\text { Premium for } \\
\text { Males }\end{array}$ & $\begin{array}{c}\text { Single } \\
\text { Premium for } \\
\text { Females }\end{array}$ \\
\hline 0 & 3642 & 5278 & 30 & 7956 & 11283 \\
1 & 3719 & 5412 & 31 & 8170 & 11573 \\
2 & 3816 & 5550 & 32 & 8390 & 11871 \\
3 & 3916 & 5692 & 33 & 8616 & 12177 \\
$\ldots$ & $\ldots$ & $\ldots$ & $\ldots$ & $\ldots$ & $\ldots$ \\
27 & 7347 & 10454 & 57 & 16173 & \\
28 & 7545 & 10723 & 58 & 16575 & \\
29 & 7747 & 11000 & 59 & 16981 & \\
\hline
\end{tabular}




\subsection{Calculation of Medical Insurance Price}

The medical insurance price of the requisitioned land should be calculated based on the amount of money paid for the individual medical insurance. Therefore, by reference to the individual medical insurance, scale of premium rate of Taipingshengshi Changjian Medical Insurance (see Table 2) of China Pacific Insurance Co., Ltd., the per capita single premium of medical insurance can be calculated based on the following equation.

\section{$\mathrm{Ym}=\mathrm{Pma} \times \mathrm{Bm}+\mathrm{Pwa} \times \mathrm{Bw}$}

In this equation, $\mathrm{Ym}$ - the per capita single premium of medical insurance

a-average age

Pma-base number of the single premium of medical insurance of male citizens at the age of a

Pwa-base number of the single premium of medical insurance of female citizens at the age of a

$\mathrm{Bm}$ - the proportion of male population to the total population

$\mathrm{Bw}-$ the proportion of female population to the total population

Table 2. Scale of Premium Rate of Taipingshengshi Changjian Medical Insurance A of China Pacific Insurance Co., Ltd. (insured till 70 years old) unit : yuan

\begin{tabular}{cccccc}
\hline $\begin{array}{c}\text { Purchasing } \\
\text { Insurance at } \\
\text { the Age of }\end{array}$ & $\begin{array}{c}\text { Single } \\
\text { Premium for } \\
\text { Males }\end{array}$ & $\begin{array}{c}\text { Single } \\
\text { Premium for } \\
\text { Females }\end{array}$ & $\begin{array}{c}\text { Purchasing } \\
\text { Insurance at } \\
\text { the Age of }\end{array}$ & $\begin{array}{c}\text { Single } \\
\text { Premium for } \\
\text { Males }\end{array}$ & $\begin{array}{c}\text { Single } \\
\text { Premium for } \\
\text { Females }\end{array}$ \\
\hline 16 & 865 & 743 & 39 & 1329 & 1128 \\
17 & 884 & 759 & 40 & 1347 & 1140 \\
18 & 903 & 775 & 41 & 1364 & 1151 \\
$\ldots$ & $\ldots$ & $\ldots$ & $\ldots$ & $\ldots$ & $\ldots$ \\
35 & 1250 & 1071 & 58 & 1335 & 1008 \\
36 & 1270 & 1086 & 59 & 1295 & 971 \\
37 & 1290 & 1101 & 60 & 1246 & 928 \\
38 & 1310 & 1115 & & & \\
\hline
\end{tabular}

\subsection{Calculation of Job Security Price}

Land is the place of employment for most farmers and is of job security function for them. Therefore, the loss of land for farmers is equal to the loss of jobs for urban residents, so the job security price of land is the price of unemployment insurance. The unemployment insurance is a government action and now is not taken over by insurance companies by means of charging a single premium. When the unemployment insurance is calculated, the years before the retirement of farmers should be worked out based on the average age of farmers and during these years, farmers should be treated as unemployed, and thus the government should pay them one-off unemployment compensation. As the number of years to receive unemployment compensation is determined by the number of years residents paying unemployment insurance before 
unemployment, the maximum number of years is only 24 months. If the resident fails to find a job in 24 months, he should receive the minimum living allowances instead of unemployment compensation. As farmers have never bought any unemployment insurance, the unemployment compensation of 2 years at most can be ignored and they can receive the minimum living allowance of 2 years. By reference to the minimum living allowances from the time of unemployment to the retirement, the equation is as follows:

Yuc $=\mathrm{M} \times(\mathrm{dm} \times \mathrm{Bm}+\mathrm{dw} \times \mathrm{Bw}-\mathrm{a})$

In this equation, Yuc-per capita job security price

$\mathrm{M}-$ minimum living allowance per capita

a- average age of citizens

$\mathrm{dm}$ - age of retirement of male citizens

$\mathrm{Bm}$ - the proportion of male population to the total population

$\mathrm{dw}$ - age of retirement of female citizens

$\mathrm{Bw}$ - the proportion of female population to the total population

In this equation, the value of $\mathrm{M}$, the minimum living allowance per capita, is the sum of annual basic living expenses per capita, annual basic medical care expenditure per capita (referring to the treatment of common diseases, not including treatment for major diseases) and annual educational expense per capita under the current education level (including compulsory education and job training).

\subsection{Calculation of Property Inheritance Price}

The Law of the People's Republic of China on Land Contract in Rural Areas currently in effect has given farmers the long-term right of use of the collective land and their right of use of land is the survival guarantee that farmers leave with their offspring. The property inheritance value of the original farmland can be calculated by calculating the education expenses that ensure the offspring of farmers receive the same education as that of the local urban residents and enable them to have the same career competence as the offspring of the urban residents. The education expenses refer to the expenses that should be used to pay for the job training which enables the offspring of farmers to receive the same education as that of the urban residents other than the nine-year compulsory education. The equation is as follows:

$$
\mathrm{Yi}=\mathrm{A} \times(\mathrm{D} 1-\mathrm{D} 2) \times \mathrm{T}
$$

In this equation, $\mathrm{Yi}$ - per capita property inheritance price

A - the annual education expense for citizens per capita between the age of 16 and 25

D1 - the average years of education of urban residents between the age of 16 and 25

D2 - the average years of education of rural residents between the age of 16 and 25

$\mathrm{T}$-the proportion of rural population between the age of 16 and 25 to the total population

Due to the great difference in the development of different areas and the ideology of people in China, the years of education of the offspring of the farmers in some areas may reach or exceed the average years of education of the offspring of the urban residents. In that case, as the equation of job security price above has included the 
education expense into the minimum living allowance per capita, M, double counting here should be avoided. That is, when D2 $\geq \mathrm{D} 1, \mathrm{Yi}=0$.

\subsection{Determination of Social Security Price of Farmland}

In those areas where farmers have other noneconomic income, land provides part of security function for farmers and the land requisition price should also include this part of social security price. Hence, the social security price per capita is related to the proportion of land revenue of farmers to their total revenue. The equation is as follows:

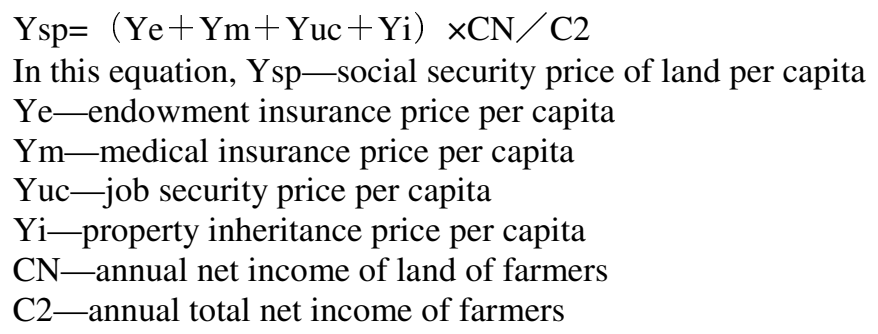

The social security price of land per capita is obtained by calculation in the equation above, while the social security price of land in a unit area is related to land area each farmer owns. The equation is as follows:

$\mathrm{V}=\mathrm{Ysp} / \mathrm{Q}$

In this equation, $\mathrm{V}$ - average social security price of a unit area

Ysp-average social security price of land per capita

Q-land area a farmer owns per capita

At present, in some areas where fine agriculture or characteristic agriculture is developed, the income of farmers from farming is far more than that of the ordinary land cultivation. However, fine agriculture and characteristic agriculture are the key supported industries of the local government, the production and management land of which will not be requisitioned. Therefore, this kind of sampling point should be eliminated and not be calculated as an exception.

In the process of farmland requisition, the insurance function of farmland to farmers is often ignored or in the actual operation, the calculation method of retirement pension of insurance companies is adopted, which result in some problems such as the extremely low compensation price. In the process of calculating endowment insurance price, medical insurance price, job security price and property inheritance price, some factors such as the inflation of prices and inflation are ignored. With the development of economy, the inflation rate and inflation of prices might change dramatically and modification should be made according to the practical situation when the social security price is calculated. Whether the structure of the social security function of farmland is complete is determined by whether the social security system of China is complete. With the perfection of social security system of China and the disappearance of limit between urban areas and rural areas, the structure of social security price of farmland will change accordingly. 


\section{References}

1. Dai, S.: Constructing Two-way Land Requisition Compensation System: Requisition and Purchase. China Real Estate Information 6, 61-63 (2004)

2. Li, L.: Predicament and Way Out of Land-lost Farmers in Guangxi Province. South Land Resources 5, 8-10 (2004)

3. Liu, Q., Li, Y., Liu, J.: Discussion on Rational Compensation Standard of Requisition of Suburb Land in China. Economic Forum 14, 10-11 (2004)

4. Guo, L., Chen, L.: Constructing Compensation and Placement Mechanism with Social Security Function for Land Requisition. Real Estate in China and Abroad Herald 18, 20-22 (2003) 